\title{
Antifungal activity, identification and biosynthetic potential analysis of fungi against Rhizoctonia cerealis
}

\author{
Xingli Zhao ${ }^{1}$, Peng Song ${ }^{1}$, Dianyun Hou${ }^{1}$, Ziliang $\mathrm{Li}^{1}$ and Zhenjie $\mathrm{Hu}^{2^{*}}$ (1)
}

\begin{abstract}
Purpose: Wheat sheath blight mainly infected by Rhizoctonia cerealis is one of the soil-borne fungal diseases of wheat worldwide and prevalent in major wheat growing areas in China at present. This study aimed to evaluate the antifungal activity of 163 endophytic fungi on $R$. cerealis. Antifungal strains were identified and their biosynthetic potential was analysed.

Methods: The antifungal activity of the strains was evaluated via dual-culture antagonism assay. The antifungal strains were identified on the basis of morphological characteristics and internal transcribed spacer gene sequencing. The polyketide synthases (PKSs) and nonribosomal peptide synthetase (NRPS) genes in antifungal strains were detected via specific amplification of chromosomal DNA.

Result: Twelve out of 163 fungal strains, including seven strains with matrix competition and five strains with antibiosis, were obtained. The twelve antifungal strains belonged to four genera: Alternaria, Ascochyta, Botryosphaeria, and Talaromyces. The inhibition rate of the seven strains with matrix competition was greater than $50 \%$, with that of Botryosphaeria dothidea S2-33 being the highest at 84.6\%. The inhibition zone of Talaromyces assiutensis R-03 amongst the five strains with antibiosis was the widest at up to $7 \mathrm{~mm}$. Among the twelve antifungal strains, the strain S2-16 contained all the genes tested, five B. dothidea strains contained PKS-II and NRPS genes, two Alternaria alternata strains only contained PKS-II gene and the remaining four strains did not contain any.

Conclusion: Results demonstrated twelve potential strains for the biocontrol of wheat sheath blight. In particular, $T$. assiutensis R-03 was determined as a promising agent. The active substances secreted by antifungal strains may be produced by other biosynthetic pathways.
\end{abstract}

Keywords: Antifungal activity, Rhizoctonia cerealis, Identification, Biocontrol gene

\section{Introduction}

Wheat is one of the major food crops in the world and it plays an important role in ensuring food security. The control of wheat disease is one of the main measures to improve wheat yield. Wheat sheath blight, also known as wheat sharp eyespot, is a widespread worldwide

\footnotetext{
*Correspondence: zhenjiehu@haust.edu.cn

${ }^{2}$ College of Horticulture and Plant Protection, Henan University of Science and Technology, Luoyang, China

Full list of author information is available at the end of the article
}

soil-borne fungal disease caused by Rhizoctonia cerealis and Rhizoctonia solani (Guo et al. 2012). Wheat sheath blight destroys conducting and mechanical tissues in the stem and other parts of the wheat, leading to necrosis of the stem wall and eventually hindrance in the transportation of nutrients and water, which results in the absence of seed in the ear of wheat (Cromey et al. 2006). This disease seriously reduces wheat quality and yield at the mild reduction of $5-20 \%$, heavy reduction of more than $50 \%$ or even without grain harvest (Cromey et al. 2002). Wheat sheath blight was first identified in 1978 in China

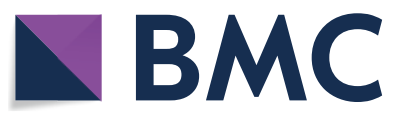

(c) The Author(s) 2021. Open Access This article is licensed under a Creative Commons Attribution 4.0 International License, which permits use, sharing, adaptation, distribution and reproduction in any medium or format, as long as you give appropriate credit to the original author(s) and the source, provide a link to the Creative Commons licence, and indicate if changes were made. The images or other third party material in this article are included in the article's Creative Commons licence, unless indicated otherwise in a credit line to the material. If material is not included in the article's Creative Commons licence and your intended use is not permitted by statutory regulation or exceeds the permitted use, you will need to obtain permission directly from the copyright holder. To view a copy of this licence, visit http://creativecommons.org/licenses/by/4.0/. 
and the incidence area of the disease has been increasing year by year, accounting for $60-80 \%$ of the total wheat planting area in severe cases, which result in an annual yield loss of approximately 50,000 tons (Yang et al. 2010). At present, wheat sheath blight mainly infected by $R$. cerealis is prevalent in major wheat growing areas in China; it results in severe losses and has become one of the important factors restricting the high and stable yield of wheat.

The prevention and control of wheat sheath blight mainly consists of chemical agents and field management at present. However, the prevention and control effects are not ideal because of the unavailability of chemical pesticides with good control effect, the pathogen's natural persistence in soils and various changeable factors in field management. Moreover, wheat varieties resistant to $R$. cerealis have not been cultivated. With the pollution from chemical pesticides becoming increasingly prominent and the people's awareness of environmental protection becoming strong, biological control becomes a promising alternative to prevent plant diseases. Biological control refers to using one or more organisms or their secondary metabolites to reduce the damage from pests (Straub et al. 2008). In particular, using microorganisms in nature to control plant diseases is an important biological approach (Yuan et al. 2017). In the last few decades, researchers have been working hard to find methods to prevent and control plant diseases from microorganisms or their secondary metabolites and many successful cases have been reported. Validamycin, which is an aminoglycoside antibiotic produced by Streptomyces hygroscopicus, has been extensively used for the control of crop diseases caused by Rhizoctonia spp. in many countries (Guirao-Abad et al. 2013). It also could control Fusarium head blight caused by Fusarium graminearum by inhibiting deoxynivalenol biosynthesis and inducing host resistance (Li et al. 2019), while it would be worth mentioning that the use of antibiotics to treat plants is banned in many countries.

In previous studies, 163 endophytic fungi, which were isolated from medicinal plant Cornus officinalis, were obtained (Zhao et al. 2020). The present study aimed to evaluate the activity of these 163 strains against $R$. cerealis via dual culture-plate antagonism and identify the strain with antifungal activity. The polyketide synthases (PKSs) and nonribosomal peptide synthases (NRPS) genes in antagonistic strains were detected to evaluate the biosynthetic potential of strains in terms of natural product discovery. PKS-I, PKS-II, and NRPS are multienzymatic and multi-domain megasynthases involved in the biosynthesis of polyketides and non-ribosomal peptides with a remarkable range of biological activities, such as antifungal, antitumor, antiparasitic, antimicrobial, and immunosuppressive (Ansari et al. 2004; Kampapongsa and Kaewkla 2016; Qin et al. 2009). The results could provide potential biocontrol strains for the control of wheat sheath blight and reliable information for further development of these strains.

\section{Materials and methods \\ Strains}

$R$. cerealis was conserved by the Plant Pathology Research Center of the College of Horticulture and Plant Protection, Henan University of Science and Technology, China. The tested 163 endophytic fungi were conserved by the Center for Evaluation and Utilization of Medicinal Plant Resources of the College of Agriculture, Henan University of Science and Technology, China. The hyphae or spores of these strains were stored in an aqueous glycerol solution $(30 \%, \mathrm{v} / \mathrm{v})$ at $-80{ }^{\circ} \mathrm{C}$. The fungal inoculum used in the assays was prepared from these frozen stocks by transferring the hyphae or spores onto potato dextrose agar (PDA) media.

\section{Evaluation of antifungal activity}

The antifungal potential of the 163 endophytic fungi against $R$. cerealis was evaluated by modifying the dual culture-plate antagonism assay described previously (Zhang et al. 2014a). All fungi were cultured on PDA media at $26{ }^{\circ} \mathrm{C}$ for 7 days. Then, 5-mm plugs of each endophyte and $R$. cerealis were co-cultured in 90-mm sterile Petri dishes, with approximately $28 \mathrm{~mL}$ of PDA yielding a final depth of $5 \mathrm{~mm}$, and incubated at $26{ }^{\circ} \mathrm{C}$ $\pm 0.5{ }^{\circ} \mathrm{C}$. The plugs were placed on the opposite sides of the centre of the Petri dishes, with a distance of $4 \mathrm{~cm}$ between them. $R$. cerealis alone was inoculated as controls. The growth radii of endophyte and $R$. cerealis and the production of an inhibition zone were monitored at regular intervals every day and recorded until the $R$. cerealis stopped growing or the size of the control colony was close to that of the plate. All control and test plates were run in triplicate, and the experiment was repeated three times.

Relative growth inhibitions (\% antagonism) were calculated as percentage of inhibition of radial growth (PIRG):

$$
\mathrm{PIRG}=\frac{\mathrm{R} 1-\mathrm{R} 2}{\mathrm{R} 1} \times 100 \%
$$

where $\mathrm{R} 1$ is the radial growth of fungi in control plates and $\mathrm{R} 2$ is the radial growth of fungi in tested plates.

The experimental data were statistically analysed by Kruskal-Wallis test, and multiple comparisons were performed by the Bonferroni method. 


\section{Morphological identification of antagonistic strains}

The fungi with antifungal activity against $R$. cerealis were cultured on PDA media at $26{ }^{\circ} \mathrm{C}$ for approximately 10 days to observe their colony characteristics, including colour, texture, topography, border type, radial growth rate, the presence of aerial mycelia and substrate mycelia, and distinctive reverse colony colour. Meanwhile, the production of spores was monitored regularly every day until the morphology and size of conidia were clearly observed under the light microscope. All the results obtained were compared with taxonomic keys (Kim et al. 1990; Wei 1979).

\section{DNA extraction, PCR amplification, and ITS sequencing}

The antagonistic isolates were subjected to DNA extraction, amplification, and sequencing of the ITS region of rRNA gene. The genomic DNA was extracted using the CTAB method (Kim et al. 1990). Universal primers ITS1 (5'-TCCGTAGGTGAACCTGCGG-3', forward) and ITS4 (5'-TCCTCCGCTTATTGATATGC-3', reverse) were used for amplification of the ITS region, which consisted of ITS1, 5.8S, and ITS2 regions of the rDNA. PCR reaction (Kusari et al. 2013) was performed in a total volume of $25 \mu \mathrm{L}$ containing $12.5 \mu \mathrm{L}$ of $2 \times$ Taq PCR Green Mix, $0.5 \mu \mathrm{L}$ of ITS1 $(10 \mu \mathrm{M}), 0.5 \mu \mathrm{L}$ of ITS4 $(10 \mu \mathrm{M}), 1 \mu \mathrm{L}$ of template DNA, and $10.5 \mu \mathrm{L}$ of sterile double-distilled water. The PCR cycling protocol (Kusari et al. 2013) consisted of an initial denaturation at $94{ }^{\circ} \mathrm{C}$ for $4 \mathrm{~min}$ and 35 cycles of denaturation, annealing and elongation at $94{ }^{\circ} \mathrm{C}$ for $30 \mathrm{~s}, 55^{\circ} \mathrm{C}$ for $30 \mathrm{~s}$, and $72{ }^{\circ} \mathrm{C}$ for $40 \mathrm{~s}$, which was followed by a final elongation step of $72{ }^{\circ} \mathrm{C}$ for $10 \mathrm{~min}$. As a negative control, the template DNA was replaced by sterile double-distilled water. After amplification, an aliquot was analysed by running on a $1 \%(w / v)$ TAE agarose gel stained with nucleic acid fuel Goldview, which was added at the volume ratio of $1 / 20$ and visualized under UV light if a clear and bright band was present. The PCR products were compared to a molecular size standard $2 \mathrm{~kb}$ plus DNA ladder. All the molecular reagents were purchased from Sangon Biotech (Shanghai, China).

When the amplification product was detected as a single bright band, it was sent to Sangon Biotech (Shanghai, China) for sequencing. For the identification of screened fungal isolates, the ITS sequences were matched with the nucleotide database by using the Basic Local Alignment Search Tool (BLAST) of the US National Centre for Biotechnology Information (NCBI). The sequences were aligned using CLUSTAL W software packaged with MEGA 7.0 under default setting. When the similarity between a particular problem sequence and a phylogenetically associated reference sequence was $\geq 99 \%$, only then the sequences were considered to be conspecific (Yuan et al. 2010). The phylogenetic tree was reconstructed and the evolutionary history was inferred using the neighbour-joining method. The robustness of the internal branches was also assessed with 1000 bootstrap replications. The evolutionary distances were computed using the Maximum Composite Likelihood method and calculated in the units of the number of base substitutions per site.

Taxonomic assignment was based on similarity with reference sequences retrieved from GenBank and in consultation with observed colony and spore morphology. The ITS sequences of the screened fungal isolates were deposited in the NCBI GenBank and accession numbers were obtained.

\section{Detection of PKS-I, PKS-II, and NRPS gene sequences}

The screened fungal isolates, which showed good antifungal activity, were selected for the detection of genes encoding PKS-I, PKS-II, and NRPSs. Three sets of primers were used to amplify these three genes and the specific information is as follows: primers for the PKS-I gene $(1200-1400 \mathrm{bp})$ were K1F (5'-TSAAGTCSAAC ATCGGBCA-3') and M6R (5'-CGCAGGTTSCSGTA CCAGTA-3'), primers for the PKS-II gene (600 bp) were $\mathrm{KS} \alpha$ (5'-TSGCSTGCTTGGAYGCSATC- $\left.3^{\prime}\right)$ and $\mathrm{KS}_{\beta}$ (5'-TGGAANCCG CCGAABCCTCT- $3^{\prime}$ ) and primers for the NRPS gene (700-800 bp) were A3F (5'-GCSTACSYSATSTACACSTCSGG-3') and A7R (5'-SASGTCVCCSGTSCGGTAS-3') (Ayuso-Sacido and Genilloud 2005).

The reaction mixture contained $12.5 \mu \mathrm{L}$ of $2 \times$ Taq PCR Green Mix, $1 \mu \mathrm{L}$ of each primer $(10 \mu \mathrm{M}), 1 \mu \mathrm{L}$ of template DNA, $1.25 \mu \mathrm{L}$ dimethyl sulfoxide, and $8.25 \mu \mathrm{L}$ of sterile double-distilled water, in a total volume of $25 \mu \mathrm{L}$. The control reaction mixtures had no DNA template. The PCR cycling protocol consisted of an initial denaturation at $94{ }^{\circ} \mathrm{C}$ for $5 \mathrm{~min}, 30$ amplification cycles of $94{ }^{\circ} \mathrm{C}$ for 1 min, $57^{\circ} \mathrm{C}$ for $1 \mathrm{~min}$ for amplification of the PKS-I and NRPS genes or $58{ }^{\circ} \mathrm{C}$ for 1 min for amplification of the PKS-II gene, $72{ }^{\circ} \mathrm{C}$ for $2 \mathrm{~min}$, and a final extension at 72 ${ }^{\circ} \mathrm{C}$ for 5 min (Ayuso-Sacido and Genilloud 2005).

\section{Results}

\section{Antifungal activity of testing fungal isolates}

The main three types of antagonism are matrix competition, mycoparasitism, and antibiosis (Kusari et al. 2013). In the present study, the antagonistic effects of the testing strains on $R$. cerealis exhibited matrix competition and antibiosis. (1) In matrix competition, the living space and the availability of nutrients for $R$. cerealis was compressed and reduced because of the rapid growth of testing strains. (2) In antibiosis, a clear halo (inhibition zone) emerged around the biomass of the testing strains because they could inhibit the growth of $R$. cerealis by secreting secondary metabolites before their mycelia 
come in physical contact. Amongst the 163 strains tested, five showed antibiosis and the other 158 showed matrix competition. In terms of matrix competition, the inhibition rate of the testing strains on $R$. cerealis ranged from negative to $72 \%$. Given that only when the inhibition rate is greater than $50 \%$ could the competitive effect be further studied, seven strains with inhibition rate of greater than $50 \%$ were listed in Table 1 . The inhibition rates increased from 53 to 84.6\%; amongst them, the strain S2-33 was the highest (Fig. 1), and the statistical analysis indicated the inhibition rates of these seven strains against wheat sheath blight were significantly different (Kruskal-Wallis test: $H=18.130, P=0.006$, Fig. 2). With regard to antibiosis, all the five antibiotic strains had clear and obvious inhibition zones ranging from 2 to $7 \mathrm{~mm}$ after 5-10 days of confrontation culture, of which

Table 1 Antagonism, ITS analysis, and detection of PKS/NRPS genes of twelve trains against Rhizoctonia cerealis

\begin{tabular}{|c|c|c|c|c|c|c|c|}
\hline \multirow[t]{2}{*}{ Strain number } & \multirow[t]{2}{*}{ Antagonism } & \multirow[t]{2}{*}{ Most closely related strain (accession number) } & \multirow{2}{*}{$\begin{array}{l}\text { GenBank } \\
\text { accession } \\
\text { number }\end{array}$} & \multirow{2}{*}{$\begin{array}{l}\text { Maximum } \\
\text { identity \% }\end{array}$} & \multicolumn{3}{|c|}{ Presence of gene } \\
\hline & & & & & PKS-I & PKS-II & NRPS \\
\hline S2-04 & MC (66.5) & Alternaria alternata (KX065011) & MG779613 & 99 & - & + & - \\
\hline S3-24 & MC (57.7) & Alternaria alternata (KX064968) & MG779589 & 99 & - & + & - \\
\hline S2-12 & MC (70.2) & Alternaria arborescens (MF462297) & MG779584 & 99 & - & - & - \\
\hline S2-16 & MC (68.7) & Ascochyta medicaginicola (KX065034) & MG779599 & 99 & + & + & + \\
\hline S1-05 & MC (56.3) & Botryosphaeria dothidea (KR709052) & MG779572 & 99 & - & + & + \\
\hline S3-04 & MC (66.0) & Botryosphaeria dothidea (MN633360) & MG779607 & 99 & - & + & + \\
\hline S2-33 & MC (84.6) & Botryosphaeria dothidea (JX275789) & MG779596 & 100 & - & + & + \\
\hline L-09 & $\mathrm{AB}(2.1)$ & Botryosphaeria dothidea (MT367874) & MG779593 & 99 & - & + & + \\
\hline S3-01 & $A B(2.0)$ & Botryosphaeria dothidea (KR708996) & MG779566 & 100 & - & + & + \\
\hline $\mathrm{R}-03$ & $\mathrm{AB}(7.1)$ & Talaromyces assiutensis (KY425740) & MG779548 & 99 & - & - & - \\
\hline R-05 & $A B(3.1)$ & Talaromyces trachyspermus (KJ482651) & MG779547 & 99 & - & - & - \\
\hline $\mathrm{R}-16$ & $A B(4.0)$ & Talaromyces trachyspermus (MH487470) & MG779549 & 99 & - & - & - \\
\hline
\end{tabular}

(1) The letters in the antagonism represent different antagonistic effect. $M C$ and $A B$ represent matrix competition and antibiosis respectively. (2) The numbers in parentheses after MC and AB represent "inhibition rate\%" and "width of the inhibition zone (mm)" respectively. (3) The signs" + " and "-" represent the presence and absence of the corresponding gene, respectively

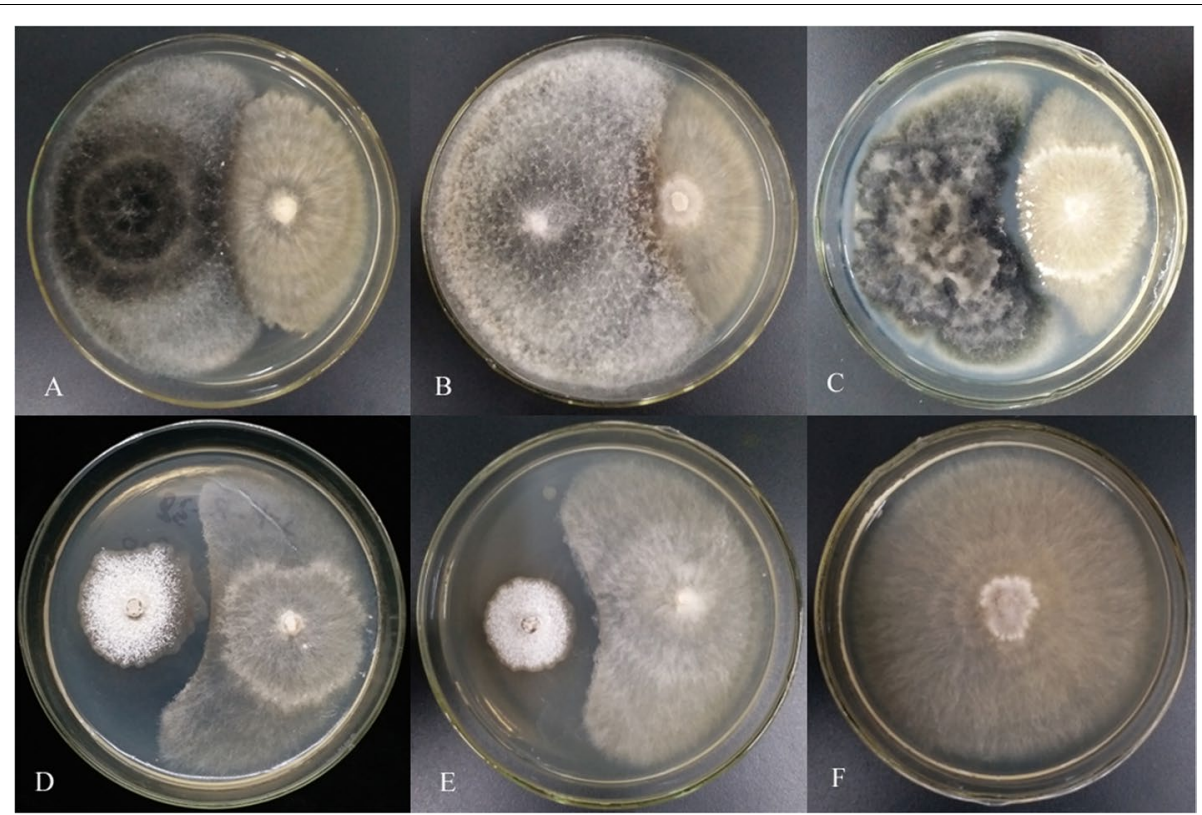

Fig. 1 Antagonism of representative strains on Rhizoctonia cerealis after 5 days of confrontation culture. A-E Strains S2-12, S2-33, S3-01, R-05, and R-03 in order, wherein $\mathbf{A}$ and $\mathbf{B}$ were matrix competition, $\mathbf{C}-\mathbf{E}$ was antibiosis, and $\mathbf{F}$ is a control, wheat sheath blight 


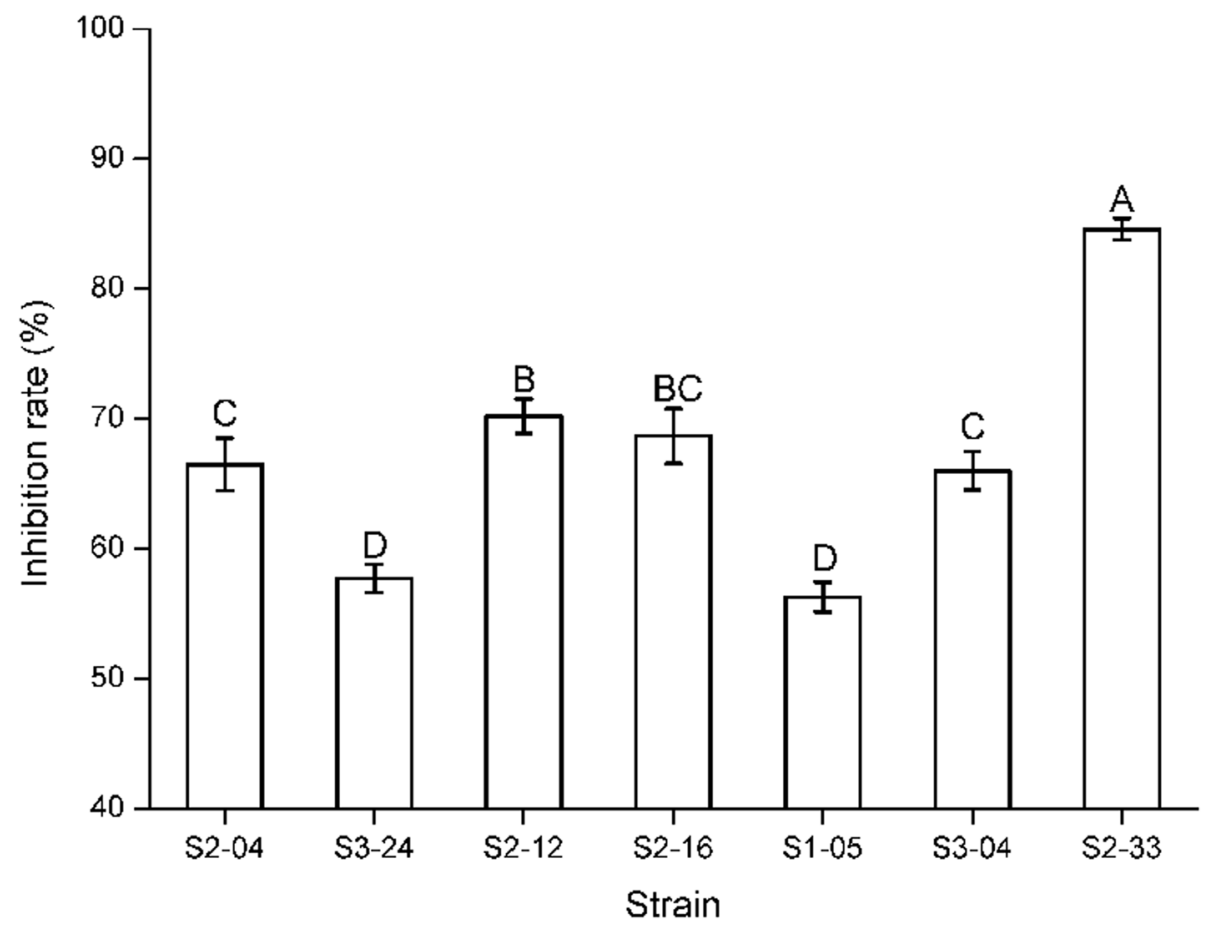

Fig. 2 Inhibition rate of seven strains against Rhizoctonia cerealis (Kruskal-Wallis test: $H=18.130, P=0.006$ ). The data in the figure was mean $\pm S D$; different letters indicates significant differences $(a=0.05)$

the inhibition zone of strain R-03 was the widest (Fig. 1), and the statistical analysis indicated the width of inhibition zone of these five strains against wheat sheath blight were also significantly different (Kruskal-Wallis test: $H=$ 12.969, $P=0.011$, Fig. 3).

\section{Identification of isolates with antifungal activity}

A total of twelve strains were screened via antagonism assay and identified on the basis of morphological characteristics and ITS (ITS1, intervening 5.8S and ITS2) sequence alignments. All the ITS sequence length of the antagonistic strains spanned around 500-600 bp. These sequences were matched with those of the most closely related fungal species (identity values higher than 99\%) in the NCBI database (http://www.ncbi.nlm.nih.gov/) through the BLAST program, combining with the morphology of colonies and spores. The similarity between the antagonistic strain sequence and the reference sequence was all above 99\%. The detailed descriptions of the antagonistic strains with respective codes, GenBank accession numbers, and closest sequence homologs are summarized in Table 1.

As for the seven strains with competition for substrate (Table 1), they belonged to genera Alternaria, Ascochyta, and Botryosphaeria. Amongst them, Alternaria contained three strains of two species, Botryosphaeria contained three strains of one species, Ascochyta had only one strain Ascochyta medicaginicola and the strain S2-33 B. dothidea had the highest inhibition rate of up to $84.6 \%$. As for the five strains with antibiosis (Table 1), three belonged to genus Talaromyces, including two species, whilst the other two belonged to $B$. dothidea. The antifungal activity of Talaromyces was generally higher than that of Botryosphaeria ones. Given that the $T$. assiutensis strain R-03 with the strongest antibiosis had the greatest potential for further development, it was used as an example and a phylogenetic tree was constructed in detail, which showed the relationship of strain R-03 to closer species with the genus Talaromyces and Trichocoma paradoxa as an outgroup (Fig. 4).

\section{Detection of PKS-I, PKS-II, and NRPS gene sequences}

Twelve antagonistic strains exhibiting good or moderate activity against $R$. cerealis were selected for the detection of PKS-I, PKS-II, and NRPS genes (Table 1). The Ascochyta medicaginicola strain S2-16 was detected to have these genes. With regard to five strains of Botryosphaeria dothidea, whether they had matrix competition or antibiosis, they were detected to have the PKS-II and NRPS genes but without the PKS-I gene. In terms of the two strains of Alternaria alternata with competition 


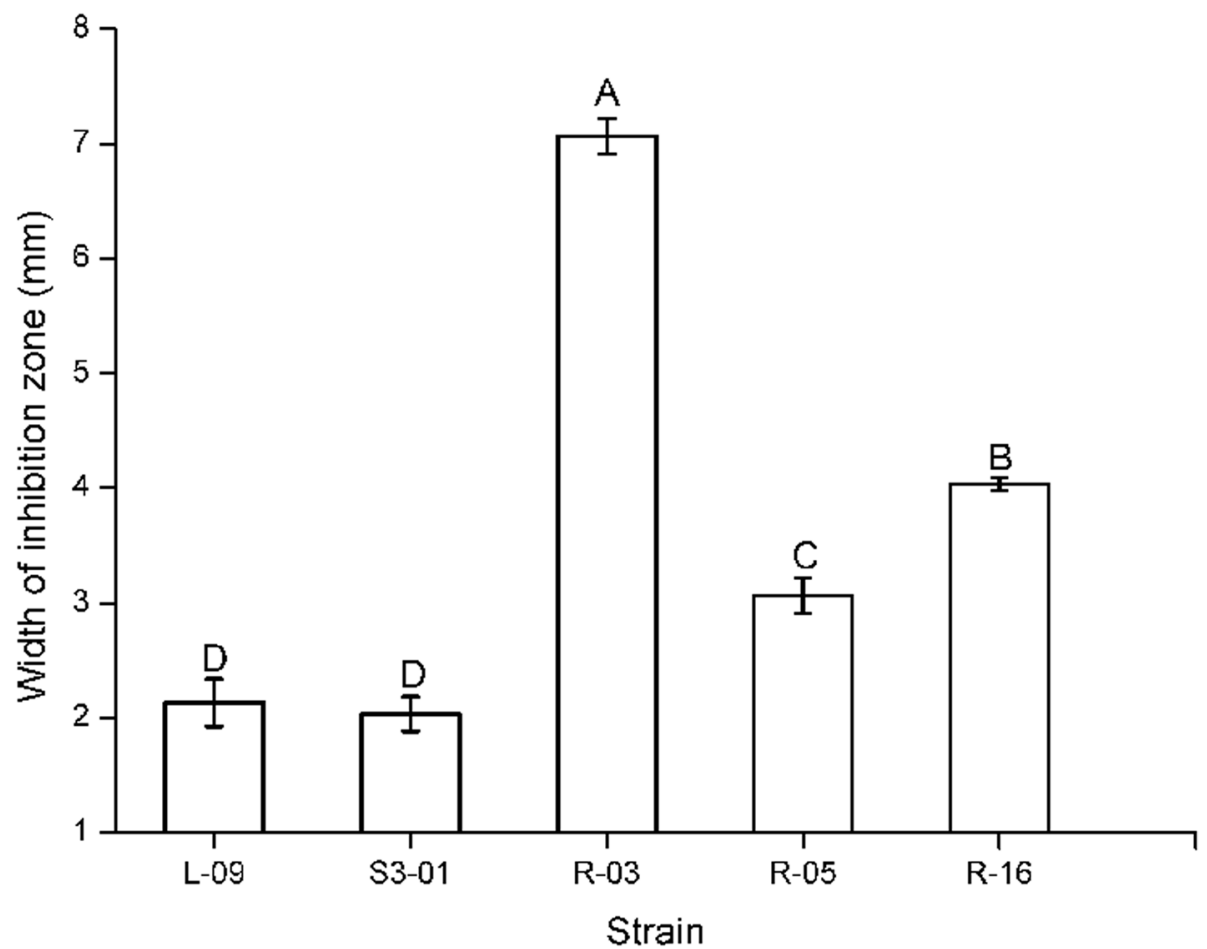

Fig. 3 Width of inhibition zone of five strains against Rhizoctonia cerealis (Kruskal-Wallis test: $H=12.969, P=0.011$ ). The data in the figure was mean $\pm \mathrm{SD}$; different letters indicates significant differences $(a=0.05)$

for substrate, they only had the PKS-II gene. However, as for the Alternaria arborescens strain S2-12 and three strains belonging to genus Talaromyces, they did not possess any of the genes mentioned.

\section{Discussion}

In using microorganisms to control wheat sheath blight, most of the reported biocontrol strains were bacteria. Nanjing Agricultural University of China reported the effects of using Bacillus subtilis B3 to control R. cerealis and the optimization scheme of fermentation conditions (Zhang et al., 1995). Jiangsu Academy of Agricultural Sciences of China has been dedicated to the screening of biocontrol bacteria of $R$. cerealis starting from the 1990s. The academy reported the biocontrol value of nearly 30 strains and performing a brief analysis of the biocontrol mechanism of some strains, and the identified strains were Paenibacillus polymyxa and Pseudomonas fluorescens (Shi et al., 1996; Lin et al., 2003; Chen et al. 2008). B. subtilis have been studied the most amongst the biocontrol bacteria of $R$. cerealis. The strain B. subtilis LF58 applied to wheat seeds could effectively reduce the incidence of wheat sheath blight infection under controlled greenhouse conditions (Innocenti et al. 2003). Wheat endophytic bacteria $B$. subtilis T10 could significantly reduce the incidence and severity of $R$. cerealis by activating peroxidase, polyphenol oxidase and $\beta-1$, 3 -glucanas, which are the defence enzymes in wheat leaves (Zhang et al. 2014b). Except for B. subtilis, Bacillus cereus was also reported to control $R$. cerealis. One endophytic bacterium $B$. cereus isolated from wheat could colonize the root system of wheat in a certain time and control the disease by inhibiting the hypha growth of $R$. cerealis (Wang and Li 2005). B. cereus strain B3-7, which had good environmental adaptability, could persistently colonize the wheat roots, effectively reduce the severity of wheat sheath blight and increase the yield of infected wheat under field conditions (Huang et al. 2014).

Few reports could be found on the use of fungi, which mainly belong to genus Trichoderma, to control wheat sheath blight. In dual culture experiments, Clonostachys rosea, Trichoderma atroviride, Trichoderma harzianum, and Trichoderma longibrachiatum could inhibit the mycelial growth of $R$. cerealis through matrix competition (Innocenti et al. 2003). Trichoderma viride LTR-2 is a strain with biocontrol potential to $R$. cerealis and the $\beta$-1, 4-glucanase gene from Bacillus megaterium strain Ap25 was recombined into strain LTR-2 chromosome DNA by using REMI technology in 1 day. Compared with the original strain, the recombinant L-10 against $R$. cerealis showed an increase in the inhibition rate by $27.0 \%$ and the control effect of greenhouse increased by $26.7 \%$ ( $\mathrm{Li}$ 


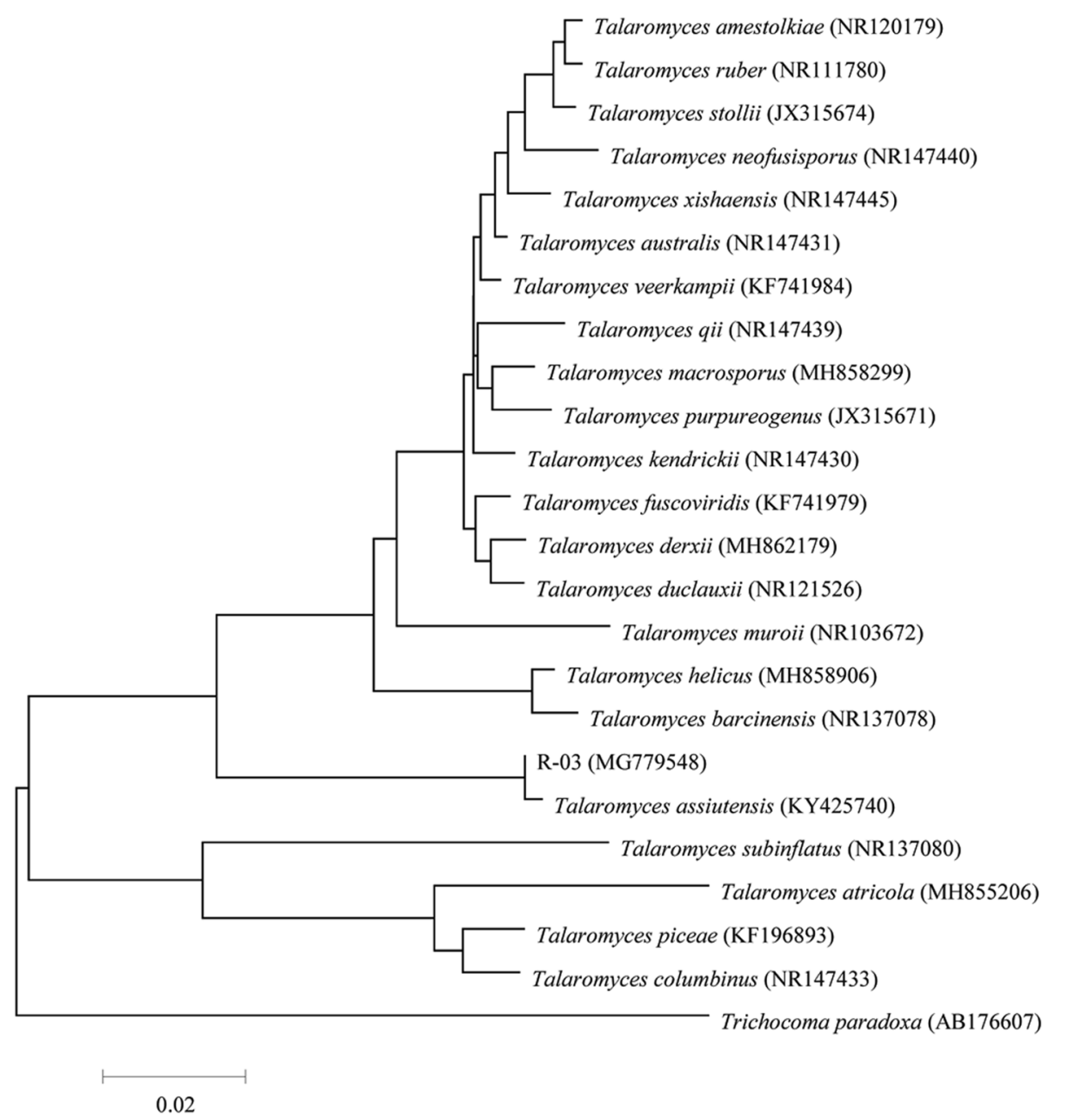

Fig. 4 The phylogenetic tree of Talaromyces assiutensis strain R-03 based on ITS sequence. The contents in parentheses represent the accession numbers in GenBank

et al. 2013). The mechanism of biocontrol fungi to control pathogenic microorganisms includes matrix competition, mycoparasitism, and antibiosis (Kusari et al. 2013). Competition and mycoparasitism mainly depend on the living propagules including spores or hyphae to inhibit the growth of pathogenic fungi. This biological fungicide, which uses the living propagules of fungi, is often affected by many natural conditions in the actual agricultural production and the effect is not significant (Duke et al. 2010). In the process of antibiosis, antagonistic and pathogenic fungi do not contact directly but inhibit or even kill pathogenic fungi, mainly via the secondary metabolites secreted by antagonists. Moreover, the secondary metabolites of microorganisms could be industrially produced by scale-up fermentation technology. The potential for further development of biological fungicides could be obviously increased if biocontrol strains with antibiosis against pathogenic fungi could be found.
Endophytic fungi are present in every plant through long-term co-evolution with host plants; they not only do not cause plant diseases, but also can benefit host plants. For instance, promoting plant growth, improving plant stress resistance, and producing some secondary metabolites to resist and inhibit the invasion of pathogens (Zheng et al. 2016). Therefore, starting from endophytic fungi is an important method to search for biocontrol fungi with antibiosis. In the present study, five strains with antibiosis against $R$. cerealis were selected from 163 cornel endophytic fungi with biocontrol potential to their host. Amongst them, T. assiutensis strain R-03 had the strongest antibiosis. During the process of culture, this strain grew slowly at a growth rate of only $1 / 4-1 / 3$ of that of $R$. cerealis. However, even under such adverse circumstances, a 7-mm inhibition zone was produced (Fig. 1). By contrast, $R$. cerealis had no effect on the growth of strain 
R-03. Meanwhile, when the colony radius of strain R-03 no longer changed over time, a circle of secretion around the edge of its colony was observed. Moreover, with the accumulation of the secretion, the inhibition zone tended to broaden. Therefore, T. assiutensis strain R-03 could continuously produce secondary metabolites with inhibitory effect on $R$. cerealis.

As for T. assiutensis, a strain isolated and identified from olive nursery substrates infested with rootknot nematodes in Morocco could kill all Meloidogyne javanica juveniles during predation tests in vitro, the most efficient nematophagous species against $M$. javanica compared with other recovered nematophagous fungi (Aït Hamza et al. 2017). In the investigation on fungi from mangrove of the South China Sea, a fungus T. assiutensis JTY2 was obtained from the leaves of Ceriops tagal (Cai et al. 2019). The ethyl acetate extract of a solid rice fermentation of the fungus exhibited antimicrobial and anti-inflammatory activities. Bioassay-guided fractionation of the bioactive extract led to the isolation of four compounds with inhibitory activities against NO production induced by lipopolysaccharide in mouse macrophage RAW 264.7 cells in vitro and one compound with broad-spectrum antibacterial activity against six terrestrial pathogenic bacteria (Cai et al. 2019). Beside the fact that a large number of studies showed that the fungi of this genus could produce various secondary metabolites (e.g., tetraenolides, diphenyl ether derivatives, anthraquinones, terpenes, indoles alkaloids, macrolides, organic acids, and cyclic peptides; Fang and Shi 2016; Fu et al. 2016; Yamashita et al. 2019), and many of these secondary metabolites exhibit good activities, such as antibacterial, antitumor, insecticidal, and enzyme inhibitors (Aït Hamza et al. 2017; Ginting et al. 2013; Li et al. 2011; Ramos et al. 2015; Yilmaz et al. 2016). Meanwhile, the fungi of this genus could also enhance plant resistance to stress and promote plant growth (Halo et al. 2020; Sahu et al. 2019). No studies are available on the application of fungus $T$. assiutensis in the control of fungal diseases at present. Therefore, the T. assiutensis strain R-03 with antibiosis obtained in the present study could be further evaluated and selected for suppressing $R$. cerealis in pot and field experiments.

In the present study, some of the 12 strains that showed good inhibitory activity against $R$. cerealis, contained three functional genes, whilst some contained two, only one and even none. This finding indicated no direct correlation between the antifungal activity and the three target genes, which was consistent with the results from previous reports (Kampapongsa and Kaewkla 2016; Zhao et al. 2011). The absence of three target genes in the three antibiotic strains belonging to the genus Talaromyces revealed that active metabolites, such as aminoglycoside, may be produced by other biosynthetic pathways (Huang et al. 2005; Kampapongsa and Kaewkla 2016). The exploration of biocontrol genes in antagonistic strains is one of the next research objectives.

\section{Conclusion}

In this study, twelve antagonistic strains against $R$. cerealis, including seven strains with matrix competition and five strains with antibiosis, were screened and identified from 163 endophytic fungi. In particular, T. assiutensis R-03 with antibiosis was determined as a promising agent for the biocontrol of wheat sheath blight. Screening of PKSs and NRPS genes in the twelve antifungal strains revealed that the active substances secreted by antifungal strains may be produced by other biosynthetic pathways. The results showed the potential strains for the biocontrol of the wheat sheath blight.

\section{Acknowledgements \\ None}

\section{Authors' contributions}

Zhao XL: perform the experiments and writing original draft. Song P: analysed the data and edited the figures. Hou DY: contributed reagents and materials. Li ZL: be responsible for picture shooting and processing. Hu ZJ: conceived and designed the experiments. The authors read and approved the final manuscript.

\section{Funding}

This work was financially supported by the Key Research Project for Colleges and Universities of Henan Province in China (grant No. 18A180013 and 18A210009) and National Innovation and Entrepreneurship Training Program for College Students in China (grant No. 202110464056).

\section{Availability of data and materials \\ N/A}

\section{Declarations}

Ethics approval and consent to participate

$\mathrm{N} / \mathrm{A}$

Consent for publication

N/A

Competing interests

The authors declare that they have no competing interests.

Author details

${ }^{1}$ College of Agriculture, Henan University of Science and Technology, Luoyang, China. ${ }^{2}$ College of Horticulture and Plant Protection, Henan University of Science and Technology, Luoyang, China.

Received: 28 April 2021 Accepted: 6 October 2021

Published online: 18 October 2021

\section{References}

Aït Hamza M, Lakhtar H, Tazi H, Moukhli A, Fossati-Gaschignard O, Miché L, Roussos S, Ferji Z, El Mousadik A, Mateille T, Boubaker H (2017) Diversity of nematophagous fungi in Moroccan olive nurseries: highlighting 
prey-predator interactions and efficient strains against root-knot nematodes. Biol Control 114:14-23. https://doi.org/10.1016/j.biocontrol.2017. 07.011

Ansari MZ, Yadav G, Gokhale RS, Mohanty D (2004) NRPS-PKS: a knowledgebased resource for analysis of NRPS/PKS megasynthases. Nucleic Acids Res 32(Web Server issue):405-413. https://doi.org/10.1093/nar/gkh359

Ayuso-Sacido A, Genilloud O (2005) New PCR primers for the screening of NRPS and PKS-I systems in Actinomycetes: detection and distribution of these biosynthetic gene sequences in major taxonomic groups. Microb Ecol 49(1):10-24. https://doi.org/10.1007/s00248-004-0249-6

Cai J, Zhou XM, Yang X, Tang MM, Liao QY, Meng BZ, Liao S, Chen GY (2019) Three new bioactive natural products from the fungus Talaromyces assiutensis JTY2. Bioorg Chem 94:103362. https://doi.org/10.1016/j.bioorg. 2019.103362

Chen LH, Zhang AX, Zhu T, Lai ZB, Wang ZH, Chen HG (2008) Identification and characterization of bacteria antagonistic to Rhizoctonia cerealis. Acta Phytopathologica Sinica 38(1):88-95. https://doi.org/10.3321/j.issn:04120914.2008.01.015

Cromey MG, Butler RC, Boddington HJ, Moorhead AR (2002) Effects of sharp eyespot on yield of wheat (Triticum aestivum) in New Zealand. New Zeal J Crop Hort 30(1):9-17. https://doi.org/10.1080/01140671.2002.9514194

Cromey MG, Parkes RA, Fraser PM (2006) Factors associated with stem base and root diseases of New Zealand wheat and barley crops. Australas Plant Path 35(4):391-400. https://doi.org/10.1071/AP06032

Duke SO, Cantrell CL, Meepagala KM, Wedge DE, Tabanca N, Schrader KK (2010) Natural toxins for use in pest management. Toxins 2(8):1943-1962. https://doi.org/10.3390/toxins2081943

Fang D, Shi CC (2016) Characterization and flocculability of a novel proteoglycan produced by Talaromyces trachyspermus OU5. J Biosci Bioeng 121(1):52-56. https://doi.org/10.1016/j.jbiosc.2015.05.001

Fu GC, Yang ZD, Zhou SY, Yu HT, Zhang F, Yao XJ (2016) Two new compounds, deacetylisowortmins a and $B$, isolated from an endophytic fungus, Talaromyces wortmannii LGT-4. Nat Prod Res 30(14):1623-1627. https://doi.org/ 10.1080/14786419.2015.1129329

Ginting RCB, Sukarno N, Widyastuti U, Darusman LK, Kanaya S (2013) Diversity of endophytic fungi from red ginger (Zingiber officinale Rosc.) plant and their inhibitory effect to Fusarium oxysporum plant pathogenic fungi. HAYATI. J Biosci 20(3):127-137. https://doi.org/10.4308/hjb.20.3.127

Guirao-Abad JP, Sánchez-Fresneda R, Valentín E, Martínez-Esparza M, Argüelles $J$ (2013) Analysis of validamycin as a potential antifungal compound against Candida albicans. Int Microbiol 16(4):217-225. https://doi.org/10. 2436/20.1501.01.197

Guo YP, Li W, Sun HY, Wang N, Yu HS, Chen HG (2012) Detection and quantification of Rhizoctonia cerealis in soil using real-time PCR. J Gen Plant Pathol 78(4):247-254. https://doi.org/10.1007/s10327-012-0390-x

Halo BA, Al-Yahyai RA, Al-Sadi AM (2020) An endophytic Talaromyces omanensis enhances reproductive, physiological and anatomical characteristics of drought-stressed tomato. J Plant Physiol 249:153163. https://doi.org/ 10.1016/j.jplph.2020.153163

Huang FL, Haydock SF, Mironenko T, Spiteller D, Li YY, Spencer JB (2005) The neomycin biosynthetic gene cluster of Streptomyces fradiae NCIMB 8233: characterisation of an aminotransferase involved in the formation of 2-deoxystreptamine. Org Biomol Chem 3(8):1410-1418. https://doi.org/ 10.1039/b501199j

Huang QB, Zhang Y, Liu FY, Wang M, Wang G (2014) Colonization dynamics of Bacillus cereus B3-7 on wheat roots and control efficiency against sharp eyespot of wheat. Acta Ecol Sin 34(10):2559-2566. https://doi.org/10. 5846/stxb201307221929

Innocenti G, Roberti R, Montanari M, Zakrisson E (2003) Efficacy of microorganisms antagonistic to Rhizoctonia cerealis and their cell wall degrading enzymatic activities. Mycol Res 107(4):421-427. https://doi.org/10.1017/ S0953756203007640

Kampapongsa D, Kaewkla O (2016) Biodiversity of endophytic actinobacteria from jasmine rice (Oryza sativa L. KDML 105) grown in Roi-Et Province, Thailand and their antimicrobial activity against rice pahogens. Ann Microbiol 66(2):587-595. https://doi.org/10.1007/s13213-015-1140-z

Kim WK, Mauthe W, Hausner G, Klassen GR (1990) Isolation of high molecular weight DNA and double-stranded RNAs from fungi. Can J Bot 68(9):1898-1902. https://doi.org/10.1139/b90-249

Kusari P, Kusari S, Spiteller M, Kayser O (2013) Endophytic fungi harbored in Cannabis sativa L.: diversity and potential as biocontrol agents against host plant-specific phytopathogens. Fungal Divers 60(1):137-151. https:// doi.org/10.1007/s13225-012-0216-3

Li HX, Huang HB, Shao CL, Huang HR, Jiang JY, Zhu X, Liu YY, Liu L, Lu YJ, Li MF, Lin YC, She ZG (2011) Cytotoxic norsesquiterpene peroxides from the endophytic fungus Talaromyces flavus isolated from the mangrove plant Sonneratia apetala. J Nat Prod 74(5):1230-1235. https://doi.org/10.1021/ np200164k

Li J, Duan YB, Bian CH, Pan XY, Yao CJ, Wang JX, Zhou MG (2019) Effects of validamycin in controlling Fusarium head blight caused by Fusarium graminearum: inhibition of DON biosynthesis and induction of host resistance. Pestic Biochem Physiol 153:152-160. https://doi.org/10.1016/j. pestbp.2018.11.012

Li JS, Chen K, Li HM, Hu JD, Wei YL, Yang HT (2013) Enhanced bio-control activity of Trichoderma viride against wheat sheath blight (Rhizoctonia cerealis) through chromosomal integration of bacillus megaterium $\beta-1$, 4-glucanase gene glu14. Acta phytopathologica sinica 43(04):393-400. https://doi.org/10.13926/j.cnki.apps.2013.04.009

Lin L, Chen HG, Liu L, Zhang AX, Wang YZ, Shi JR (2003) Screening of antagonistic bacteria against sharp eyespot of wheat and assay of their biological activity. Jiangsu J Agr Sci 19(3):187-8. https://doi.org/ CNKI:SUN:JSNB.0.2003-03-013

Qin S, Li J, Chen HH, Zhao GZ, Zhu WY, Jiang CL, Xu LH, Li WJ (2009) Isolation, diversity, and antimicrobial activity of rare actinobacteria from medicinal plants of tropical rain forests in Xishuangbanna, China. Appl Environ Microb 75(19):6176-6186. https://doi.org/10.1128/AEM.01034-09

Ramos AA, Prata-Sena M, Castro-Carvalho B, Dethoup T, Buttachon S, Kijjoa A, Rocha E (2015) Potential of four marine-derived fungi extracts as anti-proliferative and cell death-inducing agents in seven human cancer cell lines. Asian Pac J Trop Med 8(10):798-806. https://doi.org/10.1016/j. apjtm.2015.09.005

Sahu S, Prakash A, Shende K (2019) Talaromyces trachyspermus, an endophyte from Withania somnifera with plant growth promoting attributes. Environ Sustainab 2(1):13-21. https://doi.org/10.1007/s42398-019-00045-5

Shi JR, Wang YZ, Chen HG, Shen SW (1996) Screening and utilization of antagonistic bacteria for controlling sharp eyespot of wheat. Chin J Biol Control 12(4):161-4. https://doi.org/10.16409/j.cnki.2095-039x.1996.04.004

Straub CS, Finke DL, Snyder WE (2008) Are the conservation of natural enemy biodiversity and biological control compatible goals? Biol Control 45(2):225-237. https://doi.org/10.1016/j.biocontrol.2007.05.013

Wang G, Li ZQ (2005) Isolation of endophytic colonizing bacteria from wheat and its antagonism on the wheat pathogenic fungi of Rhizoctonia cerealis. Microbiol China 32(2):20-24. https://doi.org/10.3969/j.issn.0253-2654. 2005.02.005

Wei JC (1979) Handbook for fungal identification. Shanghai Science and Technology Press, Shanghai

Yamashita S, Nakagawa H, Sakaguchi T, Arima TH, Kikoku Y (2019) Detection of Talaromyces macrosporus and Talaromyces trachyspermus by a PCR assay targeting the hydrophobin gene. Lett Appl Microbiol 68(5):415-422. https://doi.org/10.1111/lam.13116

Yang GQ, Song YL, He WL, Jing S (2010) Control effects of several fungicides against the wheat sharp eyespot. Plant Prot 36(2):167-169. https://doi. org/10.3969/j.issn.0529-1542.2010.02.042

Yilmaz N, López-Quintero CA, Vasco-Palacios AM, Frisvad JC, Theelen B, Boekhout T, Samson RA, Houbraken J (2016) Four novel Talaromyces species isolated from leaf litter from Colombian Amazon rain forests. Mycol Prog 15(10-11):1041-1056. https://doi.org/10.1007/s11557-016-1227-3

Yuan Y, Feng HJ, Wang LF, Li ZF, Shi YQ, Zhao LH, Feng ZL, Zhu HQ (2017) Potential of endophytic fungi isolated from cotton roots for biological control against Verticillium wilt disease. PLoS One 12(1):e170557. https:// doi.org/10.1371/journal.pone.0170557

Yuan ZL, Zhang CL, Lin FC, Kubicek CP (2010) Identity, diversity, and molecular phylogeny of the endophytic mycobiota in the roots of rare wild rice (Oryza granulate) from a nature reserve in Yunnan, China. Appl Environ Microbiol 76(5):1642-1652. https://doi.org/10.1128/AEM.01911-09

Zhang XJ, Liu HL, Pan XM, Peng GQ, Wang JS (1995) Conditions on antagonistic substance production of B3 used for biocontrol of sharp eyespot of wheat. J Nanjing Agric Univ 18(1):26-30. https://doi.org/ CNKI:SUN:NJNY.0.1995-01-005

Zhang QH, Zhang J, Yang L, Zhang L, Jiang DH, Chen WD, Li GQ (2014a) Diversity and biocontrol potential of endophytic fungi in Brassica napus. Biol Control 72:98-108. https://doi.org/10.1016/j.biocontrol.2014.02.018 
Zhang Y, Yin SG, Xu YB, Wang G (2014b) Biocontrol efficacy of wheat endophytic bacteria Bacillus subtilis T10 strain against wheat sharp eyespot. $J$ Henan Univ (Natural Science) 44(4):456-460. https://doi.org/10.15991/j. cnki.411100.2014.04.013

Zhao K, Penttinen P, Guan TW, Xiao J, Chen Q, Xu J, Lindstrom K, Zhang LL, Zhang XP, Strobel GA (2011) The diversity and anti-microbial activity of endophytic actinomycetes isolated from medicinal plants in Panxi plateau, China. Curr Microbiol 62(1):182-190. https://doi.org/10.1007/ s00284-010-9685-3

Zhao XL, Hu ZJ, Hou DY, Xu HW, Song P (2020) Biodiversity and antifungal potential of endophytic fungi from the medicinal plant Cornus officinalis. Symbiosis 81(3):223-233. https://doi.org/10.1007/s13199-020-00696-7
Zheng YK, Qiao XG, Miao CP, Liu K, Chen YW, Xu LH, Zhao LX (2016) Diversity, distribution and biotechnological potential of endophytic fungi. Ann Microbiol 66(2):529-542. https://doi.org/10.1007/s13213-015-1153-7

\section{Publisher's Note}

Springer Nature remains neutral with regard to jurisdictional claims in published maps and institutional affiliations.
Ready to submit your research? Choose BMC and benefit from:

- fast, convenient online submission

- thorough peer review by experienced researchers in your field

- rapid publication on acceptance

- support for research data, including large and complex data types

- gold Open Access which fosters wider collaboration and increased citations

- maximum visibility for your research: over 100M website views per year

At BMC, research is always in progress.

Learn more biomedcentral.com/submissions 